\title{
WORK-FAMILY CONFLICT DAN KINERJA GURU WANITA SEKOLAH DASAR NEGERI
}

\author{
Herwanto* \\ Dewi Rustina** \\ *Program Studi Psikologi, Universitas Negeri Jakarta \\ ** Program Studi Psikologi, Universitas Negeri Jakarta
}

DOI: https://doi.org/10.21009/JPPP.051.03

\author{
Alamat Korespondensi: \\ herwanto@unj.ac.id \\ dewirustina@gmail.com
}

\begin{abstract}
This study was conducted to determine the effect of work-family conflict on the performance of female public elementary school teachers. This study uses quantitative approach, expose facto method. The technique used in this study sample was purposive sampling technique. Researchers adapted teacher performance research instruments developed based on Depdiknas theory. Work-family conflict instruments use the theory of Dawn S. Carlson and Larry J. Williams. The level of teacher performance item reliability of 0.81 , and work-family conflict of 0.71. Final respondents from this study as many as 50 people. Hypothesis test is done by using regression analysis. The result of regression analysis showed that the significance value of 0.012 is smaller than the significance level of 0.05, then there is a significant influence of work-family conflict on the performance of female elementary school teachers. The result showed negative effects which indicates that the higher work- family conflict the teacher's performance in this study will decrease. Then the results of this study is a significant difference between work-family conflict on the performance of female public elementary school teachers. The magnitude of the resulting from regression analysis by 12.3\%, while $87.7 \%$ are influenced by other factors that are not included in this study.
\end{abstract}

\section{Keywords}

work-family conflict, teacher performance, female teacher, public elementary school

\section{Pendahuluan}

Pendidikan sudah menjadi kebutuhan dasar bagi manusia. Manusia membutuhkan pendidikan untuk meningkatkan kualitas sumber daya manusia guna mencapai tingkat kehidupan bangsa yang semakin maju dan sejahtera. Dalam Undangundang Republik Indonesia No. 20 Tahun 2003 tentang Sistem Pendidikan Nasional pasal 7 tertulis bahwa "pendidikan merupakan usaha sadar dan terencana untuk mewujudkan suasana belajar dan proses pembelajaran agar peserta didik secara aktif mengembangkan potensi dirinya untuk memiliki kekuatan spiritual keagamaan, pengendalian diri, kecerdasan, akhlak mulia, serta ketrampilan yang diperlukan dirinya, masyarakat, dan negara". Mengingat pentingnya peran pendidikan, peningkatan mutu pembelajaran sangat diperlukan untuk kepentingan kualitas pendidikan, namun kualitas pendidikan Indonesia masih masuk dalam urutan bawah dibandingkan dengan negara-negara berkembang lainnya. Menurut hasil survei World Competitiveness Year Book tahun 1997-2007 menunjukkan bahwa Indonesia berada di urutan ke 39 pada tahun 1997 dan urutan ke 16 pada urutan ke 46 dari 47 negara yang disurvei. Indonesia turun peringkat menjadi urutan ke 47 dari 49 negara pada tahun 2002, dan posisi Indonesia makin terpuruk pada tahun 2007 
dengan menempati urutan ke 53 dari 55 negara yang disurvei. Rendahnya kualitas pendidikan Indonesia berdampak pada rendahnya kualitas SDM Indonesia. Menurut laporan United Nations Development Programme (UNDP), kualitas SDM Indonesia menempati urutan 109 dari 177 negara di dunia,

Salah satu faktor utama yang menentukan kualitas pendidikan adalah guru. Guru memiliki peranan terpenting dalam menciptakan sumber daya manusia yang berkualitas. Di tangan guru yang profesional akan dihasilkan peserta didik yang berkualitas, baik secara akademis, keahlian, kematangan emosional, moral dan spiritual.

Pemerintah telah membuat aturan persyaratan untuk menjadi guru sebagai usaha untuk menciptakan guru yang profesional. Dalam pasal 8 Undang-undang Nomor 14 tahun 2005 tentang guru dan dosen menyebutkan bahwa guru wajib memiliki kualifikasi akademik, kompetensi, sertifikat pendidik, sehat jasmani dan rohani, serta memiliki kemampuan untuk mewujudkan tujuan pendidikan nasional. Program sertifikasi guru yang disyaratkan pemerintah bertujuan untuk meningkatkan kinerja guru dengan ditopang oleh tunjangan profesi yang diperoleh guru bersertifikasi. Dalam kenyataan peningkatan kinerja guru yang sudah lolos sertifikasi masih belum memuaskan. Kinerja guru yang sudah disertifikasi belum meningkat secara signifikan (Kompas, 2009).

Kinerja guru pada dasarnya merupakan kinerja atau unjuk kerja yang dilakukan oleh guru dalam melaksanakan tugasnya sebagai pendidik (Dharmawati \& Nawawi, 2015). Indikator penilaian kinerja guru antara lain: (1) pada perencanaan pembelajaran yakni menyusun program tahunan, program semester, silabus, rencana pelaksanaan pembelajaran (RPP); (2) pada pelaksanaan pembelajaran yakni penggunaan alokasi waktu pembelajaran, pengelolaan/pengaturan kelas, penggunaan media dan sumber belajar, penggunaan metode serta strategi pembelajaran, penyampaian materi pelajaran; (3) pada evaluasi pembelajaran yakni pendekatan dan jenis evaluasi, penyusunan alat-alat evaluasi, pengolahan dan penggunaan hasil evaluasi. Indikator-indikator tersebut yang akan dijadikan tolok ukur di dalam mengukur kinerja guru profesional dengan tujuan agar penilaian lebih terfokus.
Dalam penelitian Eko \& Anita (2012) berjudul "Pengaruh Kinerja Guru terhadap Motivasi Belajar Siswa", kinerja guru memberikan pengaruh sebesar $35,3 \%$ terhadap motivasi belajar siswa. Dengan kinerja guru yang kurang maksimal, maka kualitas pembelajaran juga tidak akan maksimal. Akibatnya, kualitas pendidikan dan sumber daya manusia yang dihasilkan akan rendah, terutama bagi guru SD yang merupakan pengajar pertama anak, karena mendidik anakanak dari tidak bisa apa-apa menjadi bisa membaca, menulis dan menghitung adalah pekerjaan yang paling sulit dalam dunia pendidikan, hanya guru SD terutama guru kelas 1, 2, 3 yang bisa melakukan hal ini kemampuan dan kesabaran guru SMP, SMA dan dosen atau profesor tidak bisa menandingi guru SD (Viqraizin, 2015).

Guru yang melaksanakan tugasnya sering kali dihadapkan pada berbagai macam kendala yang dapat mempengaruhi tinggi rendah kinerjanya. Di antara kendala yang paling mendasar sering kali dialami oleh guru, baik secara internal maupun eksternal adalah: (1) kondisi internal yaitu, kecerdasan, keterampilan dan kecakapan, bakat, kemampuan dan minat, motif, kesehatan dan kepribadian; (2) kondisi eksternal yaitu, lingkungan keluarga, lingkungan kerja, komunikasi dengan kepala sekolah, dan sarana dan prasarana (Srinalia, 2015).

Rurin (2015) menjelaskan pada era modern saat ini tidak menutup kemungkinan wanita untuk menjunjung karier dan meraih cita-cita. Dorongan kebutuhan ekonomi dan kebutuhan akan aktualisasi diri dari kaum wanita serta isu kesetaraan gender membuat jumlah wanita yang bekerja meningkat. Menyalurkan minat dan keahlian, memperoleh status dan pengembangan diri kerap menjadi alasan bagi para wanita untuk berkarier. Kini wanita tidak lagi puas dengan pekerjaan di rumah sehingga membuat mereka memiliki ikut terjun ke dunia karier. Persoalan muncul bagi wanita yang bekerja dan sudah berkeluarga, wanita tersebut akan memiliki dua peran yang harus dijalani. Wanita sering kali mengalami dilema dalam menyeimbangkan antara karier dan rumah tangga tanpa mengorbankan tugas-tugas kewanitaannya (Mastuti 2006). Kedua peran tersebut menuntut kinerja yang sama baiknya. Banyaknya tanggung jawab yang harus dipenuhi bisa memicu munculnya stres akibat banyaknya 
beban dan tekanan yang datang baik dari sisi pekerjaan dan sisi keluarga.

Dalam menyeimbangkan tugas pekerjaan dan rumah tangga, wanita cenderung memprioritaskan tanggung jawab keluarga, sedangkan laki-laki cenderung melihat tanggung jawab dalam keluarga adalah dengan mencari nafkah sehingga ia memprioritaskan tanggung jawabnya dalam pekerjaan untuk memenuhi tanggung jawab dalam rumah tangga (Tenbrunsel et al, 1995 dalam Martin, 2002). Budaya dan peran gender Indonesia yang membuat tuntutan rumah tangga banyak dibebankan kepada kaum wanita.

Wanita yang tidak dapat membagi atau menyeimbangkan waktu untuk urusan keluarga dan bekerja dapat menimbulkan konflik keluarga dan konflik pekerjaan atau sering disebut sebagai konflik peran ganda wanita antara pekerjaan dan keluarga (work-family conflict) (Rikantika, 2015). Di satu sisi guru wanita dituntut untuk bertanggung jawab dalam mengurus dan membina keluarga secara baik, namun disisi lain sebagai seorang guru yang baik mereka dituntut pula untuk bekerja sesuai dengan standar profesionalitas seorang guru bersertifikasi dengan menunjukkan kinerja yang baik (Indriyani, 2009).

Bagi seorang wanita, peran dalam keluarga berhubungan dengan tekanan yang timbul dan menangani urusan rumah tangga dan menjaga anak, sedangkan peran dalam pekerjaan berhubungan dengan tekanan yang timbul dari beban kerja yang berlebihan serta waktu yang dibutuhkan (deadline). Kondisi tersebut sering memicu terjadinya konflik- konflik yang terjadi dalam pekerjaan dan bila tidak ditangani secara serius akan menimbulkan dampak seperti rendahnya kinerja guru yang akan mempengaruhi produktivitas guru tersebut. Greenhaus \& Beutell (1985), dalam Rurin Rikantika (2015) menyebutkan work-family conflict merupakan suatu bentuk konflik yang timbul karena seseorang mengalami kesulitan menyeimbangkan peran dalam pekerjaan dan keluarga.

Greenhaus dan Beutell (1985) mendefinisikan work-family conflict sebagai bentuk konflik antar peran dimana tekanan-tekanan peran pekerjaan dan keluarga saling tidak selaras satu sama lain dalam beberapa hal, dimana partisipasi dalam salah satu peranan tersebut menjadi lebih sulit dikarenakan tuntutan untuk berpartisipasi dalam peranan yang lain. Greenhaus (1999) mengidentifikasikan tiga tipe utama mengenai work-family conflict, yaitu konflik berdasarkan waktu (timebased conflict) terjadi karena waktu yang digunakan dalam satu peran tidak dapat digunakan untuk peran yang lain, konflik berdasarkan ketegangan (strain-based conflict) terjadi karena tuntutan terhadap waktu dan tenaga terlalu besar untuk melakukan perannya secara memadai sehingga berakibat kepada kualitas hidup secara keseluruhan, dan konflik berdasarkan perilaku (behavior-based conflict) muncul ketika suatu tingkah laku efektif untuk satu peran namun tidak efektif digunakan untuk peran yang lain.

Penelitian ini dilakukan untuk membuktikan pengaruh konflik pekerjaan-keluarga (work-family conflict) terhadap kinerja guru wanita sekolah dasar negeri. Hipotesis yang digunakan dalam penelitian ini yaitu ada pengaruh antara workfamily conflict terhadap kinerja guru wanita sekolah dasar negeri.

\section{Metode Penelitian}

Penelitian ini menggunakan pendekatan kuantitatif. Sangadji \& Sopiah (2010) mengatakan bahwa penelitian kuantitatif adalah teknik penelitian yang datanya dinyatakan dalam bentuk angka dan dianalisis dengan teknik statistik. Penelitian kuantitatif merupakan metode-metode untuk menguji teori-teori tertentu dengan cara meneliti hubungan antar variabel. Populasi dalam penelitian ini adalah guru wanita sekolah dasar negeri, bersertifikasi, sudah menikah dan memiliki anak. Untuk menentukan sampel yang akan digunakan dalam penelitian, subjek dipilih berdasarkan teknik non-probability sampling dengan jenis purposive sampling. Teknik purposive sampling adalah penentuan sampel berdasarkan pertimbangan tertentu. Teknik ini digunakan karena banyak kriteria dalam penentuan sampel yaitu guru wanita sekolah dasar negeri bersertifikasi yang sudah menikah dan memiliki anak di DKI Jakarta. Teknik pengumpulan data dalam penelitian ini menggunakan metode kuesioner berupa skala Likert. Partisipan diberikan kuesioner berisi sejumlah pernyataan, kuesioner yang dipakai menggunakan alat ukur kinerja guru yang dikembangkan berdasarkan teori Depdiknas oleh Viqraizin (2015) dengan jumlah item instrumen adalah 41 item dan Work-Family Conflict Scale 
(WFCS) yang dibuat oleh Dawn S. Carlson dari Departement of Management, College of Business, Florida State Univeresity dan Larry J. Williams dari Departement of Management, School of Business, Virginia Commonwealth University pada tahun 2000 dengan judul Construction and Initial Validation of Multidimensional Measeure of Work-Family Conflict dan dibuat berdasarkan definisi work-family conflict milik Greenhaus \& Butell (1985). Instrumen ini mengukur enam dimensi konflik peran ganda, yaitu tiga bentuk konflik peran ganda (time, strain, dan behavior) dan dua arah dari konflik peran ganda (work interference with family (WIF) dan family interference with work (FIW))

\section{Hasil Penelitian dan Diskusi}

Berdasarkan hasil yang diperoleh dari pengujian hipotesis dengan menggunakan analisis regresi menunjukkan bahwa terdapat pengaruh signifikan work-family conflict terhadap kinerja guru pada guru wanita sekolah dasar negeri. Selain itu analisis regresi juga dilakukan untuk menganalisis pengaruh signifikansi dimensi workfamily conflict terhadap kinerja guru. Dari keenam dimensi work-family conflict yang dihitung menunjukkan bahwa dua dimensi memiliki pengaruh yang signifikan terhadap kinerja guru wanita sekolah dasar negeri. Peneliti juga memperinci pengaruh dimensi work-family conflict terhadap kinerja guru wanita sekolah dasar negeri dimana perhitungan menunjukkan terdapat pengaruh yang signifikan pada dimensi work-family conflict konflik berdasarkan tekanan dimana peran pekerjaan mengganggu peran keluarga (strain-based WIF) dan konflik berdasarkan perilaku dimana peran pekerjaan mengganggu peran keluarga (behavior-based WIF) terhadap kinerja guru wanita sekolah dasar negeri.

Berdasarkan hasil perolehan korelasi ganda (R), maka variabel work-family conflict memengaruhi variabel kinerja guru sebesar $12.3 \%$, sedangkan $87,7 \%$ dipengaruhi oleh faktor yang tidak diteliti dalam penelitian ini. Dimensi workfamily conflict yaitu konflik berdasarkan tekanan dimana peran pekerjaan mengganggu peran keluarga (strain-based WIF) memengaruhi kinerja guru sebesar $7.6 \%$ sedangkan $92.4 \%$ dipengaruhi oleh faktor yang tidak diteliti dalam penelitian ini. Dimensi work family conflict yaitu konflik berdasarkan perilaku dimana peran pekerjaan mengganggu peran keluarga (behavior-based WIF) mempengaruhi kinerja guru sebesar $15.9 \%$ sedangkan $84.1 \%$ dipengaruhi oleh faktor yang tidak diteliti dalam penelitian ini. Jika dilihat dari tabel coeficients bahwa dimensi yang paling mempengaruhi kinerja guru adalah konflik berdasarkan perilaku dimana peran pekerjaan mengganggu peran keluarga (behavior-based WIF) dengan nilai beta sebesar 0.399. Hasil ini sejalan dengan penelitian yang dilakukan oleh Indriyani (2009) yang menyatakan bahwa work-family conflict menyebabkan benturan tanggung jawab di tempat kerja dan tanggung jawab di rumah. Konflik yang timbul dalam keluarga biasanya akan berpengaruh pada kinerja seseorang. Workfamily conflict merupakan suatu keadaan atau pertentangan dalam diri seseorang terkait dengan konflik peran yang diembannya. Pertentangan antar peran yang dimiliki oleh individu membuat hambatan dalam pemenuhan peran yang lainnya. Greenhaus dan Beutell (dalam Wulandari \& Wibowo, 2013), juga menyatakan bahwa workfamily conflict sebagai suatu bentuk konflik peran dalam diri seseorang yang muncul karena adanya tekanan peran dari pekerjaan yang bertentangan dengan tekanan peran dari keluarga.

Pengaruh yang dihasilkan work-family conflict terhadap kinerja guru sesuai dengan asumsi teori yaitu pengaruh yang dihasilkan work-family conflict terhadap kinerja guru bersifat negatif atau berlawanan yang artinya apabila individu memiliki work-family conflict yang tinggi maka kinerja guru akan rendah. Hasil temuan di lapangan, didapatkan sama yaitu work-family conflict memiliki pengaruh negatif terhadap kinerja guru. Hal ini menunjukkan bahwa jika work-family conflict meningkat maka kinerja guru responden pada penelitian ini akan mengalami penurunan. 
Responden merasa pemenuhan tanggung jawab dalam rumah tangga mengganggu tanggung jawab dalam pekerjaannya sebagai guru sehingga menyebabkan rendahnya kinerja guru. Faktor usia anak terakhir yang dimiliki responden dan besarnya jumlah anggota responden juga memengaruhi tingkat work-family conflict yang di rasakan oleh guru wanita sekolah dasar negeri. Responden yang memiliki anak diusia pra-sekolah sebanyak 15 orang dengan persentase $30 \%$ dan usia sekolah sebanyak 23 orang dengan persentase $46 \%$. Hal ini membuat responden merasa tertekan dengan peran yang ditanggungnya, di satu sisi ia harus memperhatikan anaknya secara penuh karena usia anak yang menduduki usia pra-sekolah yang masih terbilang sangat muda dan usia anak sekolah pun juga menuntut perhatian penuh dari orang tua untuk memantau nilai dan perkembangan mental yang baik untuk mencegah anak terjerumus ke hal-hal negatif, tetapi disisi lain juga harus menjalankan tanggung jawabnya sebagai guru yang bekerja. Dalam gambaran responden penelitian berdasarkan jumlah anggota keluarga, 18 responden memiliki jumlah anggota keluarga 4 orang dalam persentase sebesar $46 \%$, 15 orang responden memiliki jumlah anggota keluarga 5 orang dalam persentase sebesar $30 \%$, semakin besar anggota keluarga akan memungkinkan munculnya work-family conflict. Hal ini didukung oleh Stroner dan Charles (1990) yang menyatakan bahwa time pressure dan family size merupakan faktor-faktor yang mempengaruhi work-family conflict. Semakin banyak waktu yang digunakan untuk keluarga semakin sedikit waktu yang digunakan untuk menyelesaikan pekerjaan, dan semakin banyak anggota keluarga maka semakin banyak berpotensi menimbulkan konflik. Hal ini juga didukung Duxbury dan Higgins (1991) mengatakan bahwa work-family conflict adalah sumber stres yang akan berakibat buruk pada kesehatan, menjadikan turunnya peran orang tua dalam pengasuhan anak dan menurunnya kinerja sebagai pekerja serta kepuasan hidup dan mental yang rendah. Kurangnya waktu yang tersedia untuk memenuhi tugas dan tanggung jawab dari peran sebagai guru dan sebagai ibu rumah tangga menyebabkan munculnya workfamily conflict.

Dari pembahasan yang telah diuraikan, maka dapat disimpulkan bahwa work-family conflict dapat mempengaruhi kinerja guru yang terjadi pada diri guru wanita sekolah dasar negeri yang menjalankan dua peran sekaligus yakni pemenuhan tuntutan sebagai ibu rumah tangga dan pemenuhan tuntutan sebagai guru yang merupakan pekerjaannya.

\section{Kesimpulan}

Berdasarkan hasil pengujian hipotesis secara statistik, diperoleh kesimpulan bahwa terdapat pengaruh yang signifikan antara work-family conflict terhadap kinerja guru pada guru wanita sekolah dasar negeri. Pengaruh yang dihasilkan bersifat negatif atau berlawanan. Besar pengaruh work-family conflict terhadap kinerja guru wanita sekolah dasar negeri sebesar $12.3 \%$ dan $87.7 \%$ lainnya dipengaruhi oleh faktor lain yang tidak diteliti dalam penelitian ini. Hal ini menunjukkan bahwa jika work-family conflict meningkat maka kinerja guru responden pada penelitian ini akan mengalami penurunan.

\section{Daftar Pustaka}

Aryee, S., Fields, D., \& Luk, V. (1999). A CrossCultural Test of A Model of The WorkFamily Interface. Journal of management, 25(4), 491-511.

Bahri, S. (2011). Faktor yang Mempengaruhi Kinerja Guru SD di Dataran Tinggimoncong Kabupaten Gowa Provinsi Sulawesi Selatan. Jurnal Medtek, 3.

Calson, D. D., Kacmar, K. M., \& Williams, L., J. (2000). Construction and initial validation of multidimensional measure of workfamily conflict. Journal of Vacational Behavior, 56, 249-276. 
Christine, W. S., Oktorina, M., \& Mula, I. (2011). Pengaruh Konflik Pekerjaan dan Konflik Keluarga terhadap Kinerja dengan Konflik Pekerjaan Keluarga sebagai Intervening Variabel (Studi pada Dual Career Couple di Jabodetabek). Jurnal Manajemen dan Kewirausahaan (Journal of Management and Entrepreneurship), 12(2), pp-121.

Duxbury, L. E., \& Higgins, C. A. (1991). Gender Differences in Work-Family Conflict. Journal of Applied Psychology. 76(1), 6074.

Frone, M. R., Russell, M., \& Cooper, M. L. (1994). Relationship Between Job and Family Satisfaction: Causal or Noncausal Covariation?. Journal of Management, 20(3), 565-579.

Greenhaus, J. H., \& Beutell, N. J. (1985). Sources of Conflict Between Work and Family Roles. Academy of Management Review. 10(1), 76-88.

Nurhayati, B. (2006). Faktor-Faktor yang Mempengaruhi Profesionalisme dan Kinerja Guru Biologi di SMAN Kota Makassar Sulawesi Selatan. Mimbar Pendidikan, 4(25), 64-70.

Indriyani, A. (2009). Pengaruh Konflik Peran Ganda dan Stress Kerja terhadap Kinerja Perawat Wanita Rumah Sakit (Studi pada Rumah Sakit Roemani Muhammadiyah Semarang (Doctoral dissertation, Program Pascasarjana Universitas Diponegoro).

Kartowagiran, B. (2011). Kinerja Guru Profesional (Guru Pasca Sertifikasi). Jurnal Cakrawala Pendidikan, 3(3).

Kinerja Guru Bersertifikasi Belum Memuaskan, (Selasa, 6 Oktober 2009), Kompas. Diakses dari: http://www.google.co.id/ amp/s/app.kompas.com/amp/edukasi/read/ 2009/10/10/06/18242090/kinerja.guru.bers ertifikasi.belum.memuaskan.
Mangkunegara, A. A. P., \& Puspitasari, M. (2015). Kecerdasan Emosi Guru, Stres Kerja, Dan Kinerja Guru SMA. Jurnal Kependidikan, 45(2).

Netemeyer, R. G., James S. B. \& McMurrian, R. (1996). Development and Validation of Work-Family Conflict and Family-Work Conflict Scales. Journal of Applied Psychology. 81(4), 400- 410.

Rangkuti, A. A. (2012). Konsep dan Teknik Analisis data Penelitian Kuantitatif Bidang Psikologi dan Pendidikan. Jakarta: FIP Press.

Rangkuti, A. A. (2015). Statistika Parametrik \& Non-Parametrik. Jakarta: FIP Press.

Rikantika, R. (2015). Pengaruh Work Family Conflict Dan Kepuasan Kerja Terhadap Kinerja Karyawan (Studi Pada Pegawai Wanita Badan Pusat Statistik (Bps) Provinsi Daerah Istimewa Yogyakarta) (Doctoral Dissertation, Fakultas Ekonomi Universitas Muhammadiyah Yogyakarta).

Srinalia, S. (2015). Faktor-Faktor Penyebab Rendahnya Kinerja Guru Dan Korelasinya Terhadap Pembinaan Siswa: Studi kasus di SMAN 1 Darul Imarah Aceh Besar. Jurnal Ilmiah Didaktika, 15(2), 193-207.

Sugiyanto, E., Irawati, Z., \& Padmantyo, S. (2016). Konflik Pekerja-Keluarga Dan Pengaruhnya Terhadap Kinerja Pegawai (Studi Kasus rumah Sakit Berbasis Islam di Surakarta). IQTISHADIA Jurnal Kajian Ekonomi dan Bisnis Islam, 9(1).

Sugiyono. (2014). Metode Penelitian Kuantitatif, Kualitatif, dan $R \& D$. Bandung Alfabeta.

Susanto, H. (2013). Faktor-faktor yang Mempengaruhi Kinerja Guru Sekolah Menengah Kejuruan. Jurnal Pendidikan Vokasi, 2(2). 
Viqraizin, V. V. (2015). Pengaruh Kompetensi Pedagogik Dan Keuasan Kerja Terhadap Kinerja Guru Sekolah Dasar Se Kecamatan Gondokusuman Yogyakarta. Yogyakarta: Universitas Negeri Yogyakarta.
Wulandari, S. (2013). Hubungan Family-WorkConflict dengan Kinerja Perawat Perempuan di RSUD Dr. R. Goeteng Taroenadibrata Purbalingga. Depok: Universitas Indonesia. 